\title{
Molecular characterization of the noble crayfish (Astacus astacus L.) population from Pomeranian lakes (north-western Poland) based on mitochondrial DNA
}

\author{
L. Skuza ${ }^{1,2, \star}$, S. Keszka ${ }^{3}$, R. Panicz ${ }^{3}$ and P. Śmietana ${ }^{2,4}$ \\ ${ }^{1}$ Cell Biology Department, Faculty of Biology, University of Szczecin, Wąska 13 str., 70-415 Szczecin, Poland \\ 2 The Center for Molecular Biology and Biotechnology, Faculty of Biology, University of Szczecin, Wasska 13 str., $70-415$ Szczecin, Poland \\ 3 Department of Aquaculture, Faculty of Food Sciences and Fisheries, West Pomeranian University of Technology Szczecin, Kazimierza \\ Królewicza 4, 71-550 Szczecin, Poland \\ 4 Department of Ecology and Environment Protection, Faculty of Biology, University of Szczecin, Waska 13, 71-415 Szczecin, Poland
}

Received June 15, 2015 - Revised December 27, 2015 - Accepted December 31, 2015

\begin{abstract}
The genetic variability between individuals from five crayfish (Astacus astacus L.) populations was determined. The analysis was based on sequences variations of mitochondrial DNA (cytochrome oxidase subunit I (COI) and 16S ribosomal DNA. Mitochondrial DNA sequences are widely used to detect genetic variation within and between populations. Data analysis revealed the existence of two COI haplotypes - most common haplotype Hap01 and one new haplotype, differed only in one substitution. Analysis of the 16S rDNA sequences obtained showed no differences in nucleotide composition. The results of the analysis are important part of project "Active protection of noble crayfish in lakes of Pomeranian Complex Landscape Parks" financed by Financial Mechanism of the European Economic Area 2014-2016.
\end{abstract}

Key-words: Astacus astacus / genetic diversity / mtDNA / haplotype / Pomerania lakes

\begin{abstract}
Résumé - Caractérisation moléculaire de la population écrevisse à pattes rouges (Astacus astacus L.) des lacs de Poméranie (nord-ouest de la Pologne) à partir de l'ADN mitochondrial. La variabilité génétique entre les individus de cinq populations d'écrevisses à pattes rouges (Astacus astacus L.) a été déterminée. L'analyse a été basée sur les variations de séquences de l'ADN mitochondrial (sous-unité de la cytochrome oxydase I (COI) et l'ADN ribosomal 16S. Les séquences d'ADN mitochondrial sont largement utilisées pour détecter une variation génétique au sein et entre les populations. L'analyse des données a révélé l'existence de deux haplotypes COI - l'haplotype le plus commun Hap01 et un nouvel haplotype, différant en une seule substitution. L'analyse des séquences d'rDNA 16S n'a montré aucune différence dans la composition des nucléotides. Les résultats de l'analyse sont une partie importante du projet «Protection active de l'écrevisse à pattes rouges dans les lacs des Parcs Paysagers Poméraniens » financé par le Mécanisme Financier de l'Espace Economique Européen de 2014 à 2016.
\end{abstract}

Mots-clés : Astacus astacus / diversité génétique / ADNmt / haplotype / lac de Poméranie

\section{Introduction}

The freshwater crayfish in Poland are represented by two crayfish species, the noble crayfish, Astacus astacus Linnaeus 1758, and the narrow-clawed crayfish, Astacus leptodactylus Eschscholtz 1823. It is the largest freshwater invertebrate (Holdich, 2002) and very sensitive bioindicator of changes in the water environment (Gondko et al., 1992). Unfortunately in over the last two decades they have diminished in numbers in Polish lakes and rivers (Śmietana, 2001; Śmietana et al., 2004; Schulz et al., 2006a). An essential prerequisite

^ Corresponding author: skuza@univ.szczecin.pl for the protection of species is the knowledge of genetic variations within and between remaining populations (Avise, 2004; Riffel and Schreiber, 1995; Haig, 1998) and the protection should be carried out by restocking the species (Strużyński and Śmietana, 1999; Śmietana, 2001; Schulz et al., 2006a).

For describing the genetic structure of noble crayfish a variety of methods have been applied: allozymic variation (Fevolden et al., 1994), RAPD (Schulz, 2000), microsatellite length variation in the rDNA ITS1 region (Edsman et al. 2002), ISSR (Schulz et al., 2004) as well as mtDNA COI gene analysis (Schrimpf et al., 2011, 2014).

Mitochondrial DNA is powerful instrument to detect genetic variation within and between populations. For this reason 
two most popular mitochondrial region were used as a phylogeographic markers: cytochrome oxidase subunit I (COI) and $16 \mathrm{~S}$ ribosomal DNA. Mitochondrial cytochrome oxidase I (COI) gene has recently gained more attention in developing DNA barcodes for species identification and biodiversity analysis, while the $16 \mathrm{~S}$ rDNA is often used for studies at middle categorical levels such as in families or genera (Gerber et al., 2001).

Smietana (2013) in his research indicates that the populations studied belong to the strongest populations (evaluated by population density - catch per unit effort (CPUE) - Table 1) of the species found in the waters of the Polish lakes (Figure 1). Due to the dramatic rate of extinction the species in the recent years on this area (Śmietana, 2013) the results of the research are of essential importance for the development of strategy restitution of noble crayfish in Polish lakes. At present in this area a species restoration programme entitled "Active protection of the noble crayfish in lakes of the Pomeranian Complex of Landscape Parks" financed by Financial Mechanism of the European Economic Area 2014-2016 is being implemented. The project focuses on a detailed inventory of water bodies that meet the requirements of effective restitution of noble crayfish and restocking new populations with the use of semi-natural breed YOY.

Taking into account the above, the aims of the present work were: the study of the current genetic structure of Polish populations of noble crayfish through the use of a fragment of mitochondrial COI and 16S rDNA genes and propose, based on the results, areas for conservation of A. astacus in Poland.

\section{Materials and methods}

\subsection{Sample}

Specimens of Astacus astacus L. $(N=50)$ were collected from 5 locations from NW Poland: Babinki (BA), Biwakowe (BI), Graniczne (GR), Kwisno (KW) and Sęki (SE) situated in the Bytów Lakeland using the free diving method in the autumn period in 2014 (Figure 1). The samples (the fifth pair of walking legs) were stored in $75 \%$ ethanol until DNA extraction and the animals were returned to the place where they were caught.

\subsection{DNA isolation}

DNA was extracted from the muscle tissue using High Pure PCR Template Preparation Kit (Roche Diagnostics). Both quality and concentration of the DNA were assessed by agarose gel electrophoresis and spectrophotometry (NanoDrop 2000; Thermo Scientific).

\subsection{Amplification and sequencing}

A fragment from the mtDNA COI and 16S rDNA gene were amplified using the same composition of the reaction tubes in a final volume of $25 \mu \mathrm{L}$ with $1 \times$ FastStart PCR Master (Roche), $0.2 \mu \mathrm{M}$ of each primer and $40 \mathrm{ng}$ template DNA. The primers used for amplification of $\mathrm{COI}$ were COI-F ('GCGGGGATAGTAGGAACCTC') and COI-R (5'ATTTACCGCCCCTAAAATCG') (Schrimpf et al., 2011), while the primers used for amplification of $16 \mathrm{~S}$ rDNA were 16S-F (5'CCTGTTTANCAAAAACAT3') and 16S-R 5'AGATAGAAACCAACCTGG3') (Crandall et al., 1996).

The optimal PCR programme for COI amplification included an initial denaturation (at $95{ }^{\circ} \mathrm{C}$ for $2 \mathrm{~min}$ ), followed by 35 cycles of denaturation at a temperature of $95{ }^{\circ} \mathrm{C}$ (for $45 \mathrm{~s}$ ), annealing primers at $50{ }^{\circ} \mathrm{C}$ (for $45 \mathrm{~s}$ ) and extension at $72{ }^{\circ} \mathrm{C}$ (for $1 \mathrm{~min}$ ) and a final extension step of $72^{\circ} \mathrm{C}$ for $5 \mathrm{~min}$.

The optimal PCR programme for $16 \mathrm{~S}$ rDNA amplification included an initial denaturation (at $95^{\circ} \mathrm{C}$ for $3 \mathrm{~min}$ ), followed by 30 cycles of denaturation at a temperature of $95{ }^{\circ} \mathrm{C}$ (for $1 \mathrm{~min}$ ), annealing primers at $42{ }^{\circ} \mathrm{C}$ (for $1 \mathrm{~min}$ ) and extension at $72{ }^{\circ} \mathrm{C}$ (for $1.5 \mathrm{~min}$ ) and a final extension step of $72{ }^{\circ} \mathrm{C}$ for $1.5 \mathrm{~min}$. PCR products were checked by electrophoresis in $1.8 \%$ agarose gel containing ethidium bromide and a TBE buffer ( $\mathrm{pH} 8.0$ ); the gels were visualized under UV.

The PCR products were purified and sequenced on both strands by Genomed (Poland) using the PCR primers. The sequence of the new haplotype reported in this paper has been deposited in the GenBank nucleotide sequence database with the accession number KT072746.

\subsection{DNA alignment and sequence analysis}

The nucleotide sequences were aligned using CLUSTALW software (Thompson et al., 1994). After alignment, the final sequence length used was 352 bp for COI gene and $490 \mathrm{bp}$ for $16 \mathrm{~S}$ rDNA gene. The genetic diversity estimates (haplotype diversity, $\mathrm{H}$; nucleotide diversity, $\pi$ ) were calculated using DnaSPv5.10 programme (Rozas et al., 2008).

The sequences obtained from this study were analyzed in the same data set with other sequences deposited in GenBank (Astacus astacus KF888296 - KF888325 (COI), Pontastacus leptodactylus KC789393 (COI) and a sequence of Pacifastacus leniusculus AY151519 (COI) as a outgroup.

Neighbour-Joining (NJ) method was used for phylogenetic reconstructions using the " $p$ " distance. The NJ analyses were conducted on MEGA version 6.06 (Tamura et al., 2013).

\section{Results}

Amplification with the $C O I$ and 16S rDNA primers pairs produced, in all the samples, $352 \mathrm{bp}$ size products and $490 \mathrm{bp}$ size products, respectively. Sequence analysis within 50 individuals of $A$. astcus from 5 Polish populations revealed 1 substitution in $C O I$ fragment. Only two haplotypes were detected in the $C O I$ gene region - the most common haplotype Hap01 and one unique haplotype $(\mathrm{NH})$ at low frequency (accession number KT072746), which was very similar to haplotype Hap01 and differed only in one position (221), were a substitution ( $\mathrm{G}$ to $\mathrm{A}$ ) occurs.

The species A. astacus show a haplotype diversity of 0.3333 and a nucleotide diversity of 0.00095 . The highest haplotype and nucleotide diversity were found in the population Babinki (BA), where two different haplotypes were 
Table 1. Samples of A. astacus (10 individuals per population) studied in the present work. Columns show respectively: code, population, locality and region, haplotypes found, number of polymorphic sites $(S)$, haplotype diversity $(\mathrm{Hd})$ and nucleotide diversity $(\pi)$ for $C O I$ analysis.

\begin{tabular}{|c|c|c|c|c|c|c|c|}
\hline & Code & $\begin{array}{c}\text { Population } \\
\text { size CPUE }\end{array}$ & $\begin{array}{c}\text { Lake } \\
\text { name }\end{array}$ & $\begin{array}{c}\text { Haplotypes } \\
\text { found }\end{array}$ & $\begin{array}{c}\text { Number of } \\
\text { sites polymorphic }(S)\end{array}$ & $\begin{array}{c}\text { Haplotype diversity } \\
\text { (Hd) }\end{array}$ & $\begin{array}{c}\text { Nucleotide } \\
\text { diversity }(\pi)\end{array}$ \\
\hline 1 & BA & 2.14 & Babinki & 2 & 1 & 0.3556 & 0.00091 \\
\hline 2 & BI & 0.94 & Biwakowe & 1 & 0 & 0.0 & 0.0 \\
\hline 3 & GR & 3.99 & Graniczne & 1 & 0 & 0.0 & 0.0 \\
\hline 4 & KW & 1.45 & Kwisno & 1 & 0 & 0.0 & 0.0 \\
\hline 5 & SE & 0.39 & Sęki & 1 & 0 & 0.0 & 0.0 \\
\hline
\end{tabular}

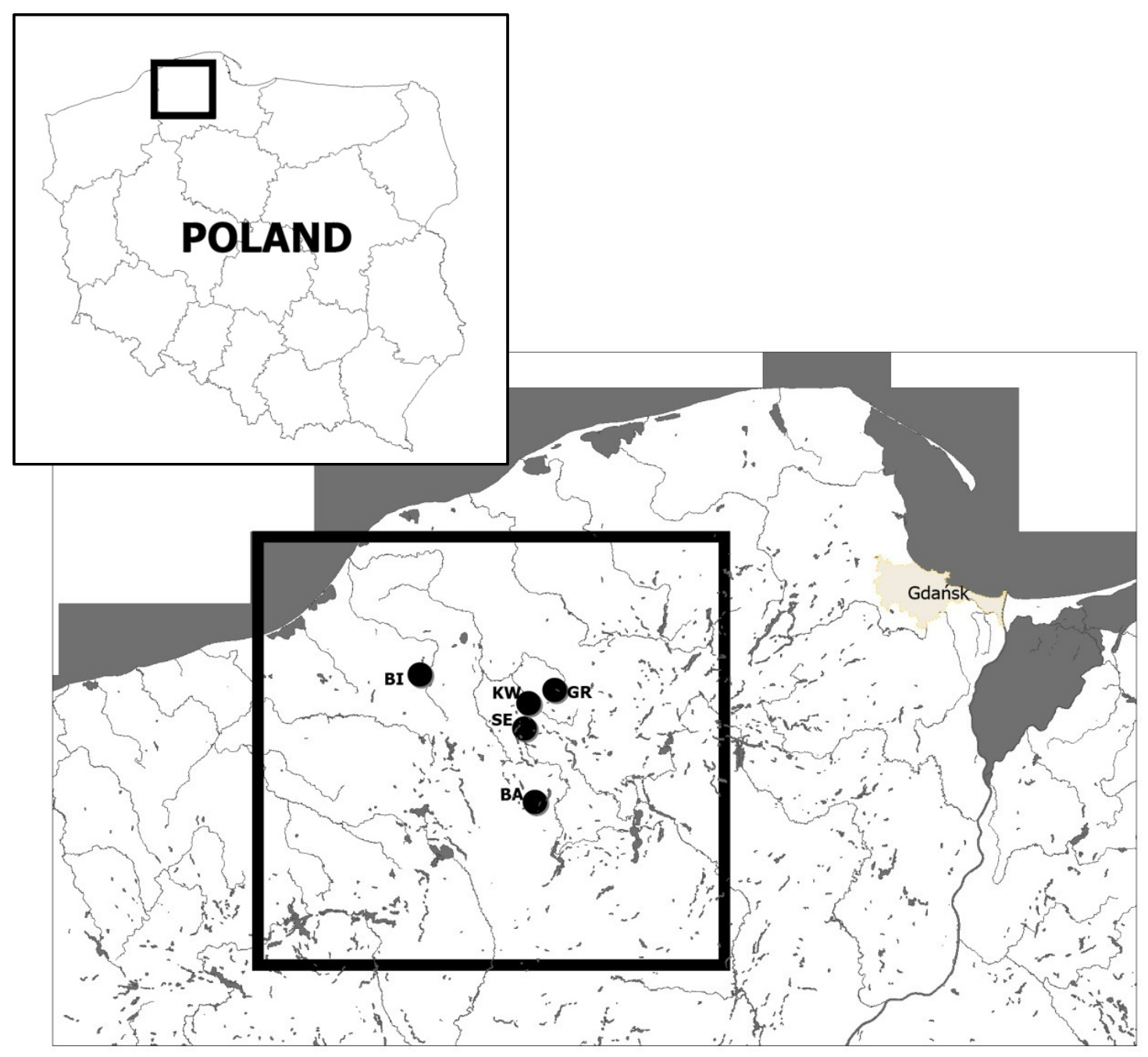

Fig. 1. Sampling locations of Polish noble crayfish included in this study. BA - lake Babinki, BI - lake Biwakowe, GR - lake Graniczne, KW - lake Kwisno, SE - lak Sęki.

detected-Hap01 and NH (only in 2 of 10 individuals) (Table 1). The remaining 4 Polish populations were monomorphic.

Cluster analysis of $\mathrm{COI}$ indicated a division of the studied species in two groups (Figure 2). The first group includes all analysed populations, while the second group corresponds to individuals from BA population carrying the new haplotype (NH) described.

Analysis of the 16S rDNA sequences obtained showed no differences in nucleotide composition. Only one haplotype across all analysed crayfish populations was found, $100 \%$ homologous with Aas01 16S ribosomal RNA gene (GenBank: KF888279).

To show the position of NH among other described haplotypes, sequences deposited in GenBank of COI A. astacus were included (Figure 3). Cluster analysis of 30 COI haplotypes described by Schrimpf et al. (2014) indicated a division of the studied species in two groups. One includes 5 Croatian haplotypes (Hap41, Hap43-46), while the second 


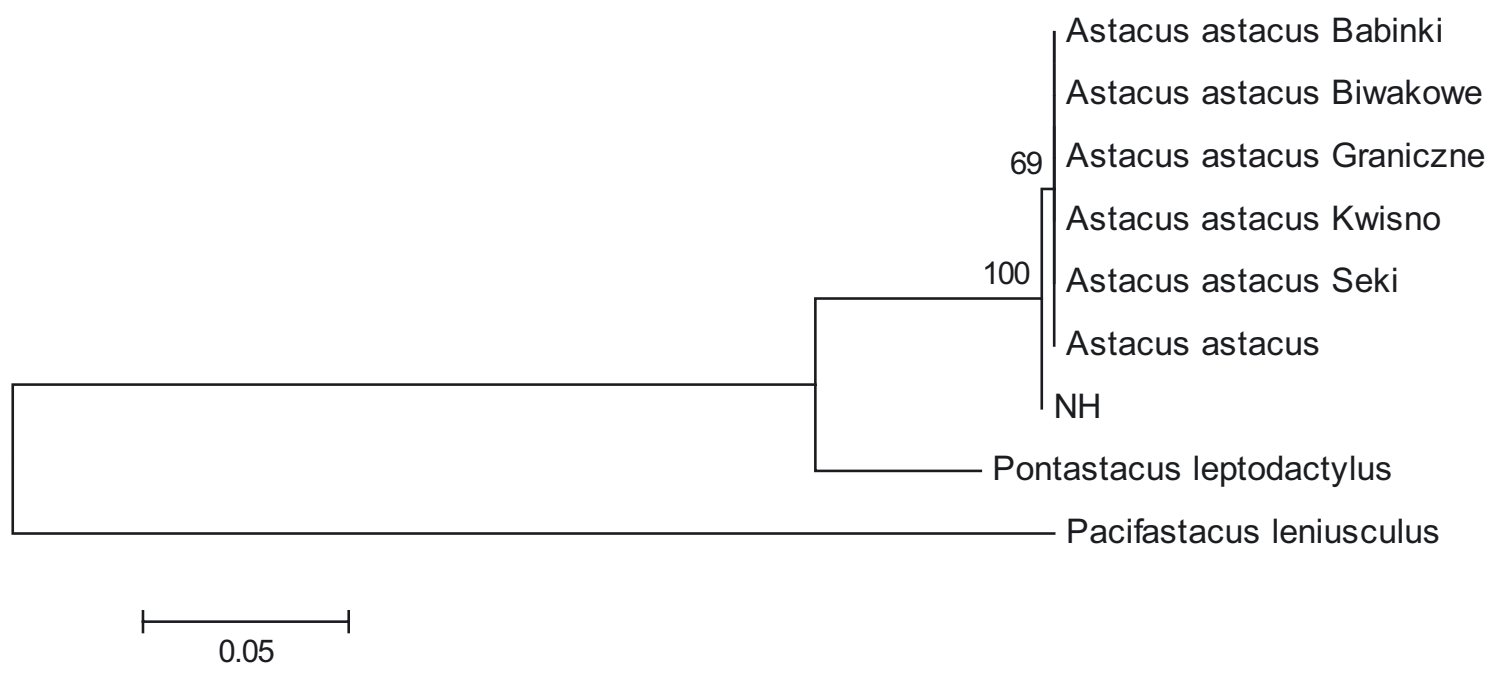

Fig. 2. Neighbor-Joining tree based on " $p$ " distances showing populations studied based on the COI data, constructed using MEGA 6.06 software. $\mathrm{NH}$ - new haplotype.

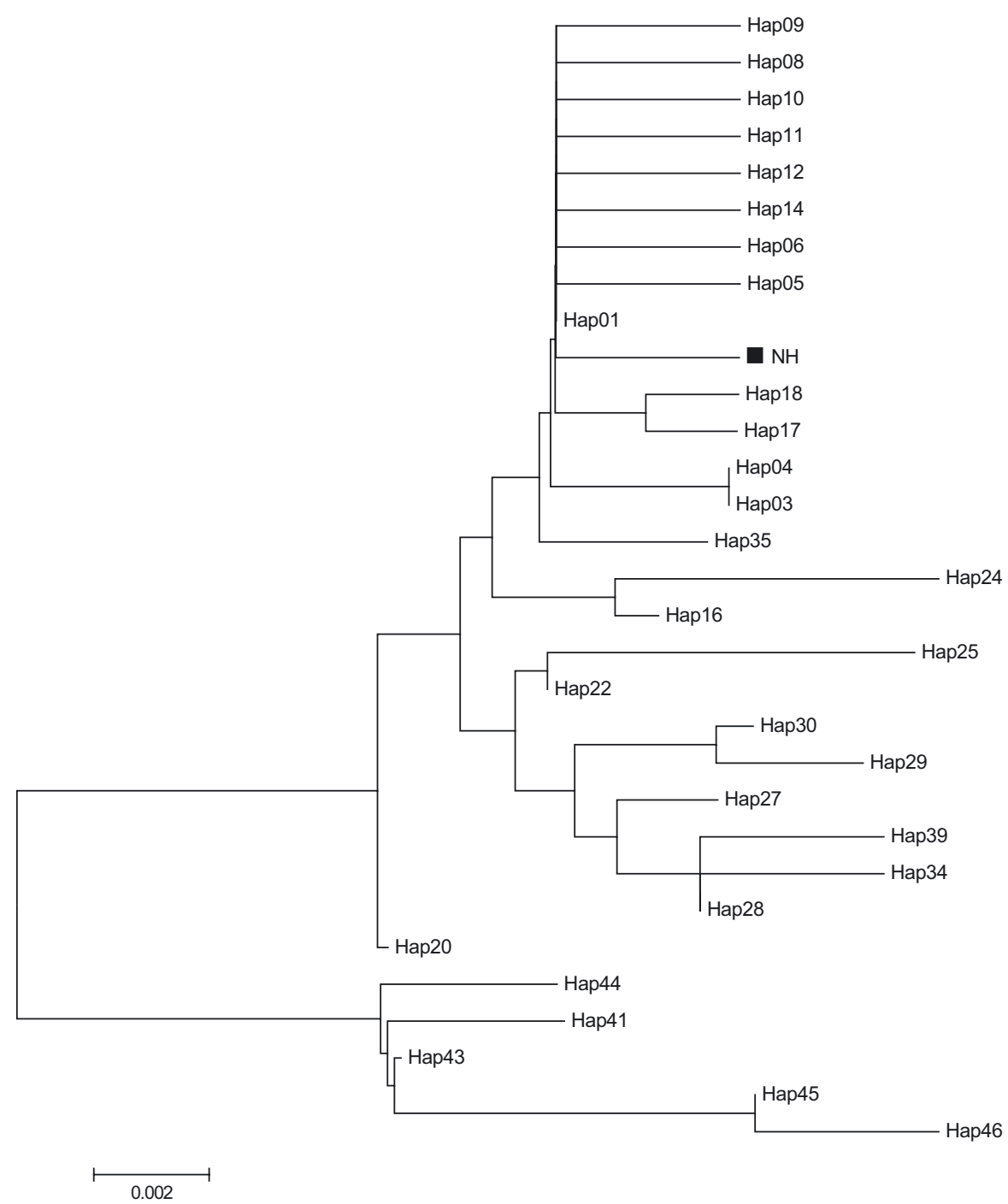

Fig. 3. Neighbor-Joining tree based on " $p$ " distances showing COI-haplotypes of A. astacus (Schrimpf et al., 2014) along with New Haplotype (NH) generated using MEGA 6.06 software. 
group the remaining haplotypes.A separate subgroup formed Hap20 from Romania. New hyplotype is grouped together with haplotypes from Germany (Hap05-06, Hap08), Bulgaria (Hap11-12, Hap14), Romania (Hap10) and Hungary (Hap09). This group includes also the most common haplotype Hap01.

\section{Discussion}

Protection of the native biodiversity is the major aim of conservation biology (Frankham et al., 2004). The knowledge of genetic variations within and between remaining populations is an essential prerequisite for the protection of species (Avise, 2004; Riffel and Schreiber, 1995; Haig, 1998). The genetic analysis of the surviving populations in terms of their internal diversity, illustrating the level of adaptation to the environment and also is necessary to choose best parents for crayfish which become restocking material.

While the stone crayfish and white-clawed crayfish species complex have already been subject to molecular studies little is known about molecular structure of noble crayfish. Early genetic studies using allozyme and RAPD markers showed low genetic diversity within noble crayfish populations (Fevolden, 1994; Schulz, 2000), while the genetic distances based on ISSR markers revealed significant differences between most of the populations examined (Schulz et al., 2004). Research conducted in the present study indicate very low level of diversity. The $16 \mathrm{~S}$ rDNA gene showed no difference between all the A. astacus from Poland, probably due to a slower rate of variation for this marker than COI, as has been observed in previous studies with other organisms (Trontelj et al., 2005; Verovnik et al., 2005; Zaccaraet al., 2004). Furthermore, only two haplotypes were detected based on COI gene analyzing.

Similar results were obtained in a study by Schrimpf et al. (2011). The authors showed the relatively low level of the variation in noble crayfish $C O I$-sequences. The study presents the results of evidence of the genetic diversity in European populations of noble crayfish, where the highest haplotype diversity and a highest number of private haplotypes were detected for the Black Sea populations, while the central European populations are significantly less variable. Absence of mtDNA differentiation and haplotype diversity would be expected if all populations came from one recent introduction event and from a very reduced number of populations or even only one population (Miura et al., 2006; Uwai et al., 2006; Pedraza-Lara et al., 2010).

The area of Pomerania and, in particular, the Bytów Lakeland is characterized by high heterogeneity of the land, which is one of factors which influence a high level of biodiversity (Schulz et al., 2006). This area was characterized also historically low population density, which makes the anthropogenic introductions relatively rare. For this reason, despite occurring relatively close to each other, subpopulations of aqueous species may be characterized originally by high genetic diversity. This may explain the occurrence of the unique haplotype in the lake Babinki, which hasn't been described in the literature so far (accession number KT072746).

Similar conclusion reached Schrimpf et al. (2014), who analyzed noble crayfish from 156 sampling locations. Based on COI and 16S rDNA the authors indicates that some areas show a distinct genetic structure with endemic haplotypes indicating that these areas were refugia for $A$. astacus and that these populations have not been subject to anthropogenic translocations.

Unique haplotype $(\mathrm{NH})$ described in this paper appeared to be very similar to 8 others from Danube and Rhine (Figure 3), also described by Schrimpf et al. (2014) and to most common haplotype Hap01, which indicate a common origin of these haplotypes.

Information provided previously by tests on the stability of population in the lakes under analysis partly confirmed the genetic results described in this paper. While analysing anthropogenic factors which have the greatest influence on the occurrence of crayfish in this area, Smietana (2013) concluded that the distance of the lake location from the nearest town/village and the number of inhabitants in the direct vicinity of the body of water are directly related. The assessment of population parameters of the noble crayfish population in selected lakes expressed by average value of the CPUE (Stuecheli, 1991; Dorn and Wojdak, 2005) showed that the most numerous populations occurred in Lake Graniczne and a slightly lower density was observed in Lake Babinki (Table 1). Graniczne Lake and Babinki Lake were situated the furthest from human settlements (27.90 km and $18.8 \mathrm{~km}$, respectively), thus being the least exposed to penetration (Śmietana, 2013).

Based on the results population from Babinki Lake could be proposed as a good area for conservation of A. astacus in Poland.

With respect to both analysed mtDNA sequences, COI gene resulted more sensitive for detecting genetic variability than $16 \mathrm{~S}$ rDNA. COI is a powerful marker for the study of the genetic variation at the intraspecific level in crayfish (Shull et al., 2005; Versteegen et al., 1997) and other crustaceans (Haye et al., 2004; Meyran et al. 1998) because its rate of molecular evolution is about threefold greater than that of $16 \mathrm{~S}$ rDNA gene (Knowlton and Weigt, 1998).

Mitochondrial DNA is a widely used marker to reconstruct the phylogeographic history of species. Here, we show that the analysis of partial COI-sequences helps to understand the genetic structure of noble crayfish. However, we realize that research should be extended and additional DNA sequences and populations should be included in the analysis to increase the resolution.

The results provide information about the structure of the studied populations that allow for the selection of parents for breeding restocking material. They will be used in terms of the development of strategies aimed at restoring the distribution of the lowlands populations of an endangered crayfish species in northern Poland.

\section{References}

Avise J.C., 2004. Molecular markers, natural history and evolution, Sinauer Associates, Sunderland, Massachusetts, 684 p.

Crandall K.A. and Fitzpatrick J.F. Jr, 1996. Crayfish molecular systematics: using a combination of procedures to estimate phylogeny. Syst. Biol., 45, 1-26.

Dorn N.J. and Wojdak J.M., 2005. Evaluating active and passive sampling methods to quantify crayfish density in a freshwater wetland, J. N. Am. Benthol. Soc., 24, 346-356. 
Edsman L., Farris J.S., Ka Llersjo M. and Prestegaard T., 2002. Genetic differentiation between noble crayfish, Astacus astacus (L.), populations detected by microsatellite length variation in the rDNA ITS1 REGION. Bull. Fr. Pêche Piscic., 367, 691-706.

Fevolden S.E., Taugbøl T. and Skurdal J., 1994. Allozymic variation among populations of noble crayfish, Astacus astacus L., in southern Norway: implications for management. Aquacult. Fish. Manage., 25, 92-935.

Frankham R., Ballou J.D. and Briscoe D.A., 2004. A primer of conservation genetics. Cambridge University Press, Cambridge, $234 \mathrm{p}$.

Gerber A.S., Loggins R., Kumar S. and Dowling T.E., 2001. Does nonneutral evolution shape observed patterns of DNA variation in animal mitochondrial genomes? Ann. Rev. Genet. 35, 539-566.

Gondko R., Babski P. and Biały L., 1992. Chroñmy raki - bioindykatory wód. In: Ochrona biosfery Bory Tucholskie, Łódź, 204-210.

Haig S., 1998. Molecular contributions to conservation. Ecology, 79, 413-425.

Haye P.A., Kornfield I. and Watling L., 2004. Molecular insights into Cumacean family relationships (Crustacea, Cumacea). Mol. Phylogenet. Evol., 30, 79-809.

Holdich D.M., 2002. Background and functional morphology. In: Holdich DM (ed.), Biology of Freshwater crayfish, Blackwell Science, Oxford, UK, 3-29

Knowlton N. and Weigt L.A., 1998. New dates and new rates for divergence across the Isthmus of Panama. Proc. Roy. Soc. B, 265, 2257-2263

Meyran J.C. and Taberlet P., 1998. Mitochondrial DNA polymorphism among alpine populations of Gammarus lacustris (Crustacea, Amphipoda). Freshw. Biol., 39, 25-265.

Miura O., Torchin M.E., Kuris A.M., Hechinger R.F. and Chiba S., 2006. Introduced cryptic species of parasites exhibit different invasion pathways. Proc. Natl. Acad. Sci., 103, 19818.

Pedraza-Lara C., Alda F., Carranza S. and Doadrio I., 2010. Mitochondrial DNA structure of the Iberian populations of the white-clawed crayfish, Austropotamobius italicus italicus (Faxon, 1914). Mol. Phylogenet. Evol., 57,, 327-342.

Riffel M. and Schreiber A., 1995. Coarse-grained population structure in Central European sculpin (Cottus gobio L.): secondary contact or ongoing genetic drift? J. Zool. Syst. Evol. Res., 33, 173-184.

Rozas J., Sánchez-DelBarrio J.C., Messenguer X. and Rozas R., 2008. DnaSP, DNA polymorphism analyses by the coalescent and other methods. Bioinformatics, 19, 2496-2497

Schrimpf A., Schulz H.K., Theissinger K., Pârvulescu L. and Schulz R., 2011. The first large-scale genetic analysis of the vulnerable noble crayfish Astacus astacus reveals low haplotype diversity in central European populations. Knowl. Manag. Aquat. Ecosyst., 401,35 .

Schrimpf A., Theissinger K., Dahlem J., Maguire I., Parvulescu L., Schulz H. K. and Schulz R., 2014. Phylogeography of noble cryfish (Astacus astacus) reveals multiple refugia. Freshw. Biol., 59, 761-776

Schulz R., 2000. Status of the noble Crayfish Astacus astacus (L.) in Germany: Monitoring protocol and the use of RAPD markers to assess the genetic structure of populations. Bull. Fr. Pêche Piscic., $356,123-138$.
Schulz H., Śmietana P., Maiwald T., Oidtmann B. and Schulz R., 2004. Case studies on the Co-occurrence of Astacus astacus (L.) and Orconectes limosus (Raf.), Snapshpts of a Slow Displacement. Freshwater Crayfish, 15, 212-219.

Schulz H., Śmietana P. and Schulz R., 2006. Estimating the human impact on population of the endangered noble crayfish (Astacus astacus L.) in north-western Poland. Aquat. Conserv. Mar. Freshw. Ecosyst., 16, 223-233.

Shull H.C., Pérez-Losada M., Blair D., Sewell K., Sinclair E.A., Lawler S., Ponniah M. and Crandall K.A., 2005. Phylogeny and biogeography of the freshwater crayfish Euastacus (Decapoda: Parastacidae) based on nuclear and mitochondrial DNA. Mol. Phylogenet. Evol., 37 (1), 249-263.

Śmietana P., 2001. On the distribution of narrow-clawed crayfish (Astacus leptodactylus Esch.) in Western Poland. Anim. Sci., 3, 25-35.

Śmietana P., 2013. Distributional conditionings and interspecific competition of the noble crayfish (Astacus astacus L.) and the spiny-cheek crayfish (Orconectes limosus Raf.) in the waters of Pomerania. Wydawnictwo Naukowe Uniwersytetu Szczecińskiego. Rozprawy i Studia - Uniwersytet Szczeciński. Vol. 860, 214 p., ISSN 0860-2751 (in Polish with English abstract).

Śmietana P., Krzywosz T. and Strużyński W., 2004. Review of the national restocking programme "Active Protection of Native Crayfish in Poland" 1999-2001. Bull. Fr. Pêche Piscic., 372-373, 289-299.

Strużyński W. and Śmietana P., 1999. On the distribution of crayfish in Poland. Freshwater Crayfish, 12, 825-829.

Stuecheli K., 1991. Trapping Bias in Sampling Crayfish with Baited Funnel Traps. N. Am. J. Fish. Manage., 11, 236-239.

Tamura K., Stecher G., Peterson D., Filipski A., and Kumar S., 2013. MEGA6: Molecular Evolutionary Genetics Analysis version 6.0. Mol. Biol. Evol., 30, 2725-2729.

Thompson J., Higgins D. and Gibson T., 1994. CLUSTAL W: improving the sensitivity of progressive multiple sequence alignment through sequence weighting, position-specific gap penalties and weight matrix choice. Nucleic Acids Res., 22, 4673-4690.

Trontelj P., Machino Y. and Sket B., 2005. Phylogenetic and phylogeographic relationships in the crayfish genus Austropotamobius inferred from mitochondrial COI gene sequences. Mol. Phylogenet. Evol., 34, 21-226.

Uwai S., Nelson W., Neill K., Wang W.D., Aguilar-Rosas L.E., Boo S.M., Kitayama T. and Kawai H., 2006. Genetic diversity in Undaria pinnatifida (Laminariales, Phaeophyceae) deduced from mitochondria genes-origins and succession of introduced populations. Phycologia, 45, 687-695.

Verovnik R., Sket B. and Trontelj P., 2005. The colonization of Europe by the freshwater crustacean Asellus aquaticus (Crustacea: Isopoda) proceeded from ancient refugia and was directed by habitat connectivity. Mol. Ecol., 14, 4355-4369

Versteegen M. and Lawler S., 1997. Population genetics of the Murray River crayfish Euastacus armatus. Freshwater Crayfish, $11,14-157$.

Zaccara S., Stefani F., Galli P., Nardi P.A. and Crosa G., 2004. Taxonomic implications in conservation management of white-clawed crayfish (Austropotamobius pallipes) (Decapoda, Astacidae) in Northern Italy. Biol. Conserv., 120, 1-10.

Cite this article as: L. Skuza, S. Keszka, R. Panicz and P. Śmietana, 2016. Molecular characterization of the noble crayfish (Astacus astacus L.) population from Pomeranian lakes (north-western Poland) based on mitochondrial DNA. Knowl. Manag. Aquat. Ecosyst., 417, 13. 